\title{
Trichoderma atroviride 102C1 Mutant: A High Endoxylanase Producer for Assisting Lignocellulosic Material Degradation
}

Mariana Menezes Quadros de Oliveira1', André Luiz Grigorevski Grigorevski-Lima', Marcella Novaes Franco-Cirigliano', Rodrigo Pires do Nascimento ${ }^{2 *}$, Elba Pinto da Silva Bon ${ }^{3}$ and Rosalie Reed Rodrigues Coelho ${ }^{1}$

1 Universidade Federal do Rio de Janeiro (UFRJ), Centro de Ciências da Saúde (CCS), Instituto de Microbiologia Prof. Paulo de Góes, Departamento de Microbiologia Geral, Avenida Carlos Chagas Filho, 373, Bloco I, Laboratório 055, CEP: 21941-902. Rio de Janeiro, RJ, Brazil

${ }^{2}$ Universidade Federal do Rio de Janeiro (UFRJ), Centro de Tecnologia (CT), Escola de Química, Departamento de Engenharia Bioquímica, Avenida Athos da Silveira Ramos, 149, Bloco E, sala 203, CEP: 21941-909 Rio de Janeiro, RJ, Brazil

${ }^{3}$ Universidade Federal do Rio de Janeiro (UFRJ), Centro de Ciências Matemáticas e Natureza (CCMN), Instituto de Química, Departamento de Bioquímica, Avenida Athos da Silveira Ramos, 149, Bloco A, sala 539, CEP: 21941-909 Rio de Janeiro, RJ, Brazil

\begin{abstract}
Endoxylanases have played an important role in many industrial processes as bleachers to kraft pulp, animal feeds and baked goods. Also, nowadays, a special attention has been devoted to the role of these enzymes in saccharification of lignocellulose biomass for biofuels production. Trichoderma species are among fungi those that have been most extensively studied, due to their efficient production of these enzymes. Among the different strategies for improving the production and biochemical aspects of enzymes of commercial interest, mutations induced using chemical agents and/or physical devices can be cited. In the present strain T. atroviride 102C1 was obtained by using UV light and nitrosoguanidine as mutagenic agents. A factorial design (central composite rotational design, CCRD) was performed to estimate the optimal levels of $\mathrm{C}$ (sugarcane bagasse) and $\mathrm{N}$ (corn steep liquor) sources for best xylanase production. After the CCRD, the 102C1 mutant strain showed increased activity of $340 \%$ for xylanase production when compared to the wild type. The enzyme was partially characterized according to its $\mathrm{pH}$ and temperature profile, also using CCRD. The characterization of $102 \mathrm{C} 1$ mutant strain as a high endoxylanase producer allows its use in biotechnological applications, particularly in the hydrolysis of lignocellulosic biomass for biorefinary proposes.
\end{abstract}

Keywords: Trichoderma atroviride mutant; Endoxylanase; Submerged fermentation; Sugarcane bagasse

\section{Introduction}

Xylanases are used in industrial applications such as in pulp prebleaching processes, as food and feed additives, in bakery processing, and in xylitol production, among others [1]. However, a great attention has been devoted to its utilization in hemicellulosic biomass degradation, aiming at production of biofuels.

Lignocellulosic biomass consists of cellulose, hemicellulose and lignin and these materials account for approximately $50 \%$ of the biomass in the world. The polysaccharides (cellulose and hemicellulose), on average, accounts for $55-75 \%$ on dry weight basis in plant cell wall and can be deconstructed into simple sugars, which further can be fermented to alcohols, such as ethanol and butanol, organic acids, acetone and glycerol [2]. Degradation and conversion of lignocellulosic biomass are attracting attention because of its potential for the development of a sustainable and environmentally friendly bioenergy, biorefining and biomaterials industry [3]. The lignocellulosic residues, which don't compete with food demand, provide a low cost feedstock for production of fuels and commodity chemicals, and thereby can offer economic, environmental and strategic advantages. Sugarcane bagasse (SB) is one of the abundantly available low-cost plant residues, which could be used for production of biofuels $[2,4]$. Moreover, corn steep liquor, a by-product of the large-scale corn milling industries is also a substrate that is inexpensive and widely available. This substrate has also being used as an efficient substitute for yeast extract and a rich source of nutrients such as organic nitrogen and vitamins for microbial culturing [5,6].

Hemicelluloses consist of heteropolymers such as xylan, glucomannan, galactoglucomannan and arabinogalactan. Xylan, the second most abundant polysaccharide in plants, is a linear polymer composed of $\mathrm{D}$-xylose units linked by glycosidic bonds and is the major hemicellulose present in plants [3]. The enzymatic hydrolysis of xylan requires the cumulative actions of endo-beta-1,4-xylanase (EC 3.2.1.8), beta-xylosidase (EC 3.2.1.37), and a series of enzymes that degrade side chain groups. Among these, endo-beta-1,4-xylanase is the most crucial enzyme that cleaves glycosidic bonds to produce short chain xylooligosaccharides of various lengths [7]. Synergic effects of alfa-arabinofuranosidase (EC 3.2.1.55), beta-D-glucuronidase (EC 3.2.1.1), and acetyl xylan esterase (EC 3.2.11.6) are required to release the side chains of xylan. However, two enzymes, namely beta1,4-endoxylanases (EC 3.2.1.8) and beta-xylosidase (EC 3.2.1.37), are sufficient to degrade the xylan back-bone [1,7].

T. atroviride is, among microorganisms, a species that shows excellent potential for secretion of an enzyme complex able to perform an efficient enzymatic conversion of biomass into ethanol [8,9]. Among the different strategies for improving the production and biochemical

*Corresponding author: Rodrigo Pires do Nascimento, Escola de Química, Centro de Tecnologia. Universidade Federal do Rio de Janeiro. Avenida Athos da Silveira Ramos, 149, Bloco E, Sala 203. Cidade Universitária. Ilha do Fundão. CEP: 21941-909, Rio de Janeiro, RJ, Brazil, Tel: + 55213938 8863; E-mail: rodrigopires@eq.ufrj.br

Received April 08, 2014; Accepted May 22, 2014; Published May 29, 2014

Citation: Oliveira MMQ, Grigorevski-Lima AL, Franco-Cirigliano MN, Nascimento RP, Bon EPS, et al. (2014) Trichoderma atroviride 102C1 Mutant: A High Endoxylanase Producer for Assisting Lignocellulosic Material Degradation. J Microb Biochem Technol 6: 236-241. doi:10.4172/1948-5948.1000150

Copyright: (c) 2014 de Oliveira MMQ, et al. This is an open-access article distributed under the terms of the Creative Commons Attribution License, which permits unrestricted use, distribution, and reproduction in any medium, provided the original author and source are credited 
Citation: Oliveira MMQ, Grigorevski-Lima AL, Franco-Cirigliano MN, Nascimento RP, Bon EPS, et al. (2014) Trichoderma atroviride 102C1 Mutant: A High Endoxylanase Producer for Assisting Lignocellulosic Material Degradation. J Microb Biochem Technol 6: 236-241. doi:10.4172/19485948.1000150

aspects of enzymes of commercial interest, mutations induced using chemical agents and/or physical devices have been cited in literature [8]. It is well known that mutants of T. atroviride are able to secrete high cellulase titers in both submerged and solid state fermentation $[8,9]$. However, as far as we are concerned, there is no report concerning the use of mutagenic agents to obtain endoxylanolytic fungi mutants. In the present study a mutant strain of T. atroviride 676 (strain $102 \mathrm{C} 1$, previously obtained in our laboratory) was studied for endoxylanase production. Being the use of agroindustrial residues an excellent strategy for a low-cost enzyme production, a central composite rotational design (CCRD) experiment was performed to estimate the optimal levels of sugarcane bagasse as $\mathrm{C}$ source and corn steep liquor as $\mathrm{N}$ source in endoxylanase production.

\section{Materials and Methods}

\section{Microorganisms}

Trichoderma atroviride $102 \mathrm{C} 1$ was obtained from the wild strain T. atroviride 676, aiming at, originally, the selection of cellulolytic strains (data not shown). The procedure to obtain the mutant strain was carried out according to Kovàcz et al. [8], with some modifications. The mutation involved two subsequent exposures to nitrosoguanidine as the mutant agent. In the first one $2.0 \mathrm{~mL}$ of a sterile solution of nitrosoguanidine $1 \%$ were added to $100 \mu \mathrm{L}$ of a spore suspension of T. atroviride 676 and the system incubated for 8 minutes. The spore suspension thus obtained was streaked in a malt extract-yeast extractagar plate. After incubation at $28^{\circ} \mathrm{C}$ for 7 days, the growing colonies were tested for cellulase activity and strain NTG21 selected. Then, for selection of $102 \mathrm{C} 1$, the same procedure was performed using spores from NTG21, however the time of exposure was 15 minutes. Although this mutation and selection was towards cellulase activity, the wild strain has shown to be, also, a good endoxylanase producer [10]

Spore suspensions were prepared according to Hopwood et al. [11] after cultivation $\left(28^{\circ} \mathrm{C} / 15\right.$ days $)$ in yeast extract-malt extract-agar medium [12] and maintained as stock cultures in $20 \%(\mathrm{v} / \mathrm{v})$ glycerol at $-20^{\circ} \mathrm{C}$. Spore concentration was determined using Neubauer counting chamber.

\section{Production of endoxylanases}

The enzyme production was performed in submerged fermentation in Erlenmeyer flasks with 1/5 of its volume of a culture medium based on the salt solution plus urea described by Mandels and Weber [13] and added of sugarcane bagasse (SB-main carbon source) and corn steep liquor (CSL-main nitrogen source). The optimization of SB and CSL concentration was carried out by employing a response surface methodology having endoxylanase activity $\left(\mathrm{U} \cdot \mathrm{mL}^{-1}\right)$ as the dependent variable and $\mathrm{C}$ source $(\mathrm{SB})$ and $\mathrm{N}$ source $(\mathrm{CSL})$ concentrations as the independent variables. A 22 full factorial central composite rotational design (CCRD) was used in order to generate 11 run combinations as described in Table 1 [14]. This design is represented by a second-order polynomial regression model, Eq. (1), to generate contour plots:

$$
\mathrm{Y}=\mathrm{b}_{0}+\mathrm{b}_{1} \mathrm{X}_{1}+\mathrm{b}_{2} \mathrm{X}_{2}+\mathrm{b}_{12} \mathrm{X}_{1} \mathrm{X}_{2}+\mathrm{b}_{11} \mathrm{X}_{1}{ }^{2}+\mathrm{b}_{2}{ }^{2} \mathrm{X}_{2}^{2}
$$

where, $\mathrm{Y}$ is the predicted response (endoxylanase activity); $\mathrm{X}_{1}$ and $\mathrm{X}_{2}$ the coded forms of the input variables (SB and CSL, respectively); $\mathrm{b}_{0}$ a constant; $\mathrm{b}_{1}$ and $\mathrm{b}_{2}$ the linear coefficients; $\mathrm{b}_{12}$ a cross-product coefficient; $b_{11}$ and $b_{22}$ the quadratic coefficients. The test factors were coded according to the following regression equation:

$$
\mathrm{x}_{\mathrm{i}}=\left(\mathrm{X}_{\mathrm{i}}-\mathrm{X}_{0}\right) / \Delta \mathrm{X}_{\mathrm{i}}
$$

\begin{tabular}{|c|c|c|c|c|c|c|}
\hline \multirow[t]{2}{*}{ Run } & \multicolumn{2}{|c|}{ Coded setting levels } & \multicolumn{2}{|c|}{ Actual levels \%(w/v) } & \multicolumn{2}{|c|}{ Endoxylanase activity (U. $\left.\mathrm{mL}^{-1}\right)$} \\
\hline & $\mathrm{X}_{1}$ & $X_{2}$ & $\mathrm{X}_{1}$ & $x_{2}$ & 0 & $\mathbf{P}$ \\
\hline 1 & -1 & -1 & 1.5 & 0.3 & 99.70 & 109.84 \\
\hline 2 & +1 & -1 & 3.5 & 0.3 & 50.80 & 69.80 \\
\hline 3 & -1 & +1 & 1.5 & 1.1 & 147.28 & 132.94 \\
\hline 4 & +1 & +1 & 3.5 & 1.1 & 266.30 & 260.83 \\
\hline 5 & -1.41 & 0 & 1.09 & 0.7 & 105.41 & 109.35 \\
\hline 6 & +1.41 & 0 & 3.91 & 0.7 & 179.93 & 171.29 \\
\hline 7 & 0 & -1.41 & 2.5 & 0.15 & 91.79 & 72.08 \\
\hline 8 & 0 & +1.41 & 2.5 & 1.26 & 208.03 & 223.04 \\
\hline 9 & 0 & 0 & 2.5 & 0.7 & 241.41 & 241.67 \\
\hline 10 & 0 & 0 & 2.5 & 0.7 & 242.58 & 241.67 \\
\hline 11 & 0 & 0 & 2.5 & 0.7 & 240.97 & 241.67 \\
\hline
\end{tabular}

Results are the mean of two experiments; O observed, $\mathrm{P}$ predict

Table 1: Values of independent variables (SB concentration $X 1$, and CSL concentration X2), used in CCRD, showing the values observed and predicted by the mathematical model for endoxylanase production by Trichoderma atroviride $102 \mathrm{C} 1$.

where, $x_{i}$ is the coded value and $X_{i}$ the actual value of the independent variable, $\mathrm{X}_{0}$ the actual value at the center point and $\Delta \mathrm{X}_{\mathrm{i}}$ is the step change value. Data analysis was performed using the Statistica 7.0.

The initial $\mathrm{pH}$ of all media was adjusted to 4.8 . The incubation was performed at $28^{\circ} \mathrm{C}$ in orbital shaking at $200 \mathrm{rpm}$ for 5 days. The supernatants, which correspond to crude enzyme extracts, were used to determine the activities of endoxylanases. Assays were performed varying the $\mathrm{C}$ and $\mathrm{N}$ sources according to the matrix shown in Table 1.

\section{Enzyme assays}

Endoxylanase (EC 3.2.1.8.) activity was estimated by reaction mixture containing $750 \mu \mathrm{L}$ of a solution of $1.0 \%(\mathrm{w} / \mathrm{v})$ oat spelts xylan $\left(\mathrm{SIGMA}^{\circledR}\right.$ ) in $50 \mathrm{mM}$ sodium citrate buffer ( $\mathrm{pH}$ 5.3) plus 0.25 $\mu \mathrm{L}$ of the supernatant. This system was incubated for $10 \mathrm{~min}$ at $50^{\circ} \mathrm{C}$. The reducing sugars concentration in the reaction mixture was determined by the dinitrosalicylic acid (DNS) method [15]. One unit (U) of enzymatic activity corresponded to $1 \mu \mathrm{mol}$ of xylose equivalents released per minute, under the assay conditions [16].

All assays were performed in duplicates, and results were expressed as average values. Variations in the multiple assays were $<10 \%$.

\section{Crude enzyme partial characterization}

A culture supernatant of 3-days fermentation [SB 3.5\% (w/v) and CSL $1.1 \%(\mathrm{w} / \mathrm{v})$ ] was used to investigate the temperature and $\mathrm{pH}$ effect on endoxylanase activity. The enzyme characterization was carried out by employing a response surface methodology having endoxylanase activity $\left(\mathrm{U} \cdot \mathrm{mL}^{-1}\right)$ as the independent variable and $\mathrm{pH}$ (between 3.0 and 7.0) and temperature (range of $40-70^{\circ} \mathrm{C}$ ) as the dependent variables. A 22 full factorial central composite rotational design (CCRD) was used in order to generate 11 run combinations as described in Table 2 [14]. This design is represented by a second-order polynomial regression model (as Equation 1, where $\mathrm{Y}$ is the predicted response endoxylanase activity; and $\mathrm{X}_{1}$ and $\mathrm{X}_{2}$ the coded forms of the input variables, $\mathrm{pH}$ and temperature, respectively) and the test factors coded according to Equation 2. Buffer solutions at $50 \mathrm{mM}$, where: sodium citrate buffer for $\mathrm{pH}$ 3.0, 3.6 and 5.0, and phosphate buffer for $\mathrm{pH} 6.4$ and 7.0 and were used at the optimal temperature previously determined. Data analysis was performed using the Statistica 7.0.

\section{Zymogram}

The culture supernatant from cells grown on the best conditions 
Citation: Oliveira MMQ, Grigorevski-Lima AL, Franco-Cirigliano MN, Nascimento RP, Bon EPS, et al. (2014) Trichoderma atroviride 102C1 Mutant: A High Endoxylanase Producer for Assisting Lignocellulosic Material Degradation. J Microb Biochem Technol 6: 236-241. doi:10.4172/19485948.1000150

\begin{tabular}{|l|c|c|c|c|c|c|}
\hline \multirow{2}{*}{ Run } & \multicolumn{2}{|c|}{ Coded setting levels } & \multicolumn{2}{c|}{ Actual levels } & \multicolumn{2}{c|}{ Endoxylanase activity (U.mL-1) } \\
\cline { 2 - 7 } & $\mathbf{X}_{1}$ & $\mathbf{X}_{\mathbf{2}}$ & $\mathbf{X}_{\mathbf{1}}$ & $\mathbf{X}_{\mathbf{2}}$ & $\mathbf{0}$ & $\mathbf{P}$ \\
\hline 1 & -1 & -1 & 3.6 & 44 & 158.90 & 122.36 \\
\hline 2 & +1 & -1 & 6.4 & 44 & 144.54 & 108.42 \\
\hline 3 & -1 & +1 & 3.6 & 66 & 17.79 & 29.54 \\
\hline 4 & +1 & +1 & 6.4 & 66 & 52.79 & 64.98 \\
\hline 5 & -1.41 & 0 & 3.0 & 55 & 19.82 & 32.38 \\
\hline 6 & +1.41 & 0 & 7.0 & 55 & 35.59 & 47.53 \\
\hline 7 & 0 & -1.41 & 5.0 & 40 & 125.70 & 172.21 \\
\hline 8 & 0 & +1.41 & 5.0 & 70 & 98.15 & 76.14 \\
\hline 9 & 0 & 0 & 5.0 & 55 & 205.88 & 205.20 \\
\hline 10 & 0 & 0 & 5.0 & 55 & 204.24 & 205.20 \\
\hline 11 & 0 & 0 & 5.0 & 55 & 205.78 & 205.20 \\
\hline
\end{tabular}

Results are the mean of two experiments; O observed, $\mathrm{P}$ predict

Table 2: Values of independent variables $(\mathrm{pH} X 1$ and temperature $\mathrm{X} 2)$, used in CCRD, showing the values observed and predicted by the mathematical model for endoxylanase activity characterization.

\begin{tabular}{|l|l|l|l|l|l|}
\hline $\begin{array}{l}\text { Sources of } \\
\text { variations }\end{array}$ & $\begin{array}{l}\text { Sum of } \\
\text { squares }\end{array}$ & $\begin{array}{l}\text { Degrees of } \\
\text { freedom }\end{array}$ & Mean square & F value & $\begin{array}{l}\text { P value } \\
\text { (prob } \mathbf{F})^{\mathbf{a}}\end{array}$ \\
\hline Model & 54746.65 & 5 & 10949.33 & 38.29 & 0.0005 \\
\hline Residual & 1429.97 & 5 & 285.99 & & \\
\hline Lack of fit & 1428.58 & 3 & 476.19 & 687.71 & 0.0015 \\
\hline Pure error & 1.38 & 2 & 0.69 & & \\
\hline Total & 56176.62 & 10 & & & \\
\hline
\end{tabular}

a Statistically significant at $90 \%$ of confidence level; R2=0.9745

Table 3: Statistical ANOVA for the model of endoxylanase production at different levels of concentration of SB and CSxL.

was analyzed by electrophoresis on denaturing $10 \%$ sodium dodecyl sulfate (SDS)-polyacrylamide gel, copolymerized with $0.1 \%(\mathrm{w} / \mathrm{v})$ oat spelts xylan (Sigma) as substrate. Electrophoresis was performed at constant voltage $(90 \mathrm{~V})$ at $4^{\circ} \mathrm{C}$ for 3 hours. After electrophoresis, gel was incubated with Triton X-100 sodium acetate $1.0 \%$ for $60 \mathrm{~min}$ in ice-bath for SDS removal, and then incubated with $50 \mathrm{mM}$ sodium citrate buffer $\mathrm{pH} 5.0$ for 10 minutes at $55^{\circ} \mathrm{C}$. For endoxylanase activity detection, the gel strip was submerged in $0.1 \%(\mathrm{w} / \mathrm{v})$ Congo Red solution for $10 \mathrm{~min}$., and then washed with $1 \mathrm{M} \mathrm{NaCl}$ solution until visualization of enzyme bands [17]. Molecular masses were calculated from mobility of standards ranging from 24 and $225 \mathrm{kDa}$ (HMW electrophoresis calibration kit-Pharmacia Biotech).

\section{Results}

\section{Enzyme production in agroindustrial residues}

The kinetic profile of enzymatic production of T. atroviride $102 \mathrm{C} 1$ in liquid media, containing the combination of different concentrations of SB and CSL was obtained after cultivation under agitation, at $28^{\circ} \mathrm{C}$ for 5 days (data not show). The maximal values of endoxylanase activity were obtained on the third day fermentation process and analyzed statistically. Endoxylanase activity varied from 50.8 to $266.3 \mathrm{U} \cdot \mathrm{mL}^{-1}$. The best result was obtained on run number 4 , where SB and CSL concentrations were $3.5 \%(\mathrm{w} / \mathrm{v})$ and $1.1 \%(\mathrm{w} / \mathrm{v})$, respectively.

The model was tested for adequacy by the ANOVA (Table 3). For SB+CSL combination (Table 1), the computed $\mathrm{F}$ value (38.29) indicates that the model was significant at a high confidence level. The probability $\mathrm{P}$ value was also very low $(<0.1)$ indicating the significance of the model. The coefficient of variation $\left(\mathrm{R}^{2}=0.97\right)$ also indicates a very good correlation between the experimentally observed and predicted values. The mathematical model representing the endoxylanase activity (Y) for the combination SB + CSL in the experimental region studied can be expressed by Equation (3).

$$
\mathrm{Y}=241.67+21.96^{*} \mathrm{X}_{1}-50.98^{*} \mathrm{X}_{1}{ }^{2}+53.53^{*} \mathrm{X}_{2}-47.34^{*} \mathrm{X}_{2}{ }^{2}+41.98^{*} \mathrm{X}_{1} \mathrm{X}_{2}+
$$
0.69243

The independent variable SB concentration had a significant effect on the interactions. The regression analysis for the experiment using the combination SB + CSL, Equation 3, show the significant coefficients of the full second-order polynomial model of endoxylanase production, determined by Student's T test and P values.

The resulting surface response plots showing the effect of substrate concentration on the endoxylanase production by T. atroviride $102 \mathrm{C} 1$ is presented in Figure 1. Besides maximum endoxylanase activity, observed at $3.5 \% \mathrm{SB}$ and $1.1 \% \mathrm{CSL}$, the surface response suggests a second good level of enzyme activity $\left(242.58 \mathrm{U} \cdot \mathrm{mL}^{-1}\right)$ in central area (2.5\% SB and $0.7 \% \mathrm{CSL}$ ).

\section{Optimal pH and temperature for enzymatic activity}

The $\mathrm{pH}$ and temperature profiles for endoxylanase activity were obtained from crude enzymatic extract of T. atroviride $102 \mathrm{C} 1$ grown in the optimal conditions: 3 days incubation, $3.5 \%(\mathrm{w} / \mathrm{v}) \mathrm{SB}$ and $1.1 \%$ $(\mathrm{w} / \mathrm{v})$ CSL. According to the data presented in Table 2, the maximum endoxylanase activity of $205.9 \mathrm{U} \cdot \mathrm{mL}^{-1}$ was observed at $55^{\circ} \mathrm{C}$ and $\mathrm{pH} 5.0$ (Figure 2). The analysis of the resulting surface response plots revealed that the maximal endoxylanase activity occurred in acidic conditions as well as higher temperatures.

The model was tested for adequacy by the ANOVA (Table 4). The model F-value of 12.46 indicates that the model was significant at a high confidence level. The probability $\mathrm{P}$ value was also very low

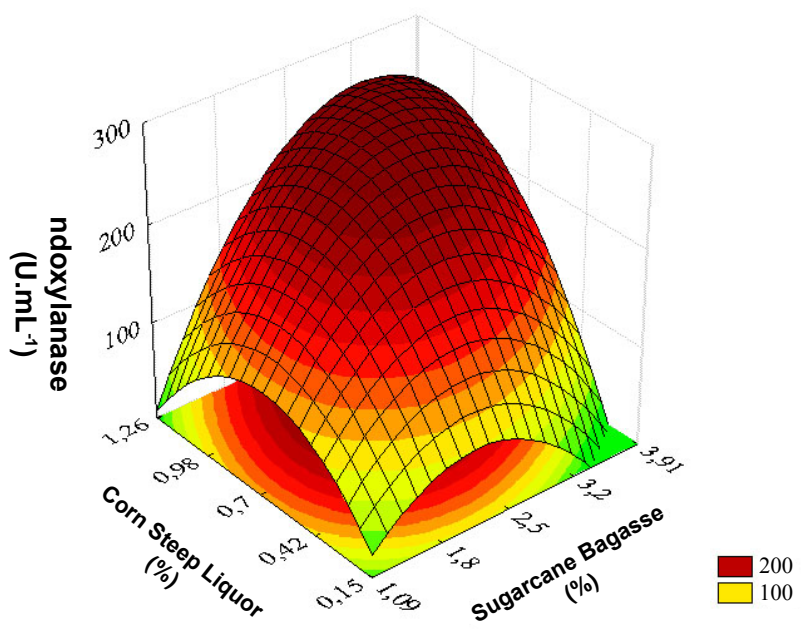

Figure 1: Response surface for endoxylanase production by $T$. atroviride $102 \mathrm{C}$ using SB and CSL concentration as dependent variables. The full factorial central composite design $\left(2^{2}\right)$ used response surface methodology to predict the best point for endoxylanase production. The values are shown in Table 1.

\begin{tabular}{|l|l|l|l|l|l|}
\hline $\begin{array}{l}\text { Sources of } \\
\text { variations }\end{array}$ & $\begin{array}{l}\text { Sum of } \\
\text { squares }\end{array}$ & $\begin{array}{l}\text { Degrees of } \\
\text { freedom }\end{array}$ & Mean square & F-value & $\begin{array}{l}\text { p-value } \\
\text { (prob>F) }\end{array}$ \\
\hline Model & 50292.00 & 4 & 12573.00 & 12.46 & 0.0046 \\
\hline Residual & 6054.65 & 6 & 1009.11 & & \\
\hline Lack of fit & 6052.97 & 4 & 1513.24 & 1793.64 & 0.0006 \\
\hline Pure error & 1.69 & 2 & .84 & & \\
\hline Total & 56346.65 & 10 & & & \\
\hline
\end{tabular}

aStatistically significant at $90 \%$ of confidence level; $R^{2}=0.8925$

Table 4: Statistical ANOVA for the model of endoxylanase activity at different levels of $\mathrm{pH}$ and temperature. 


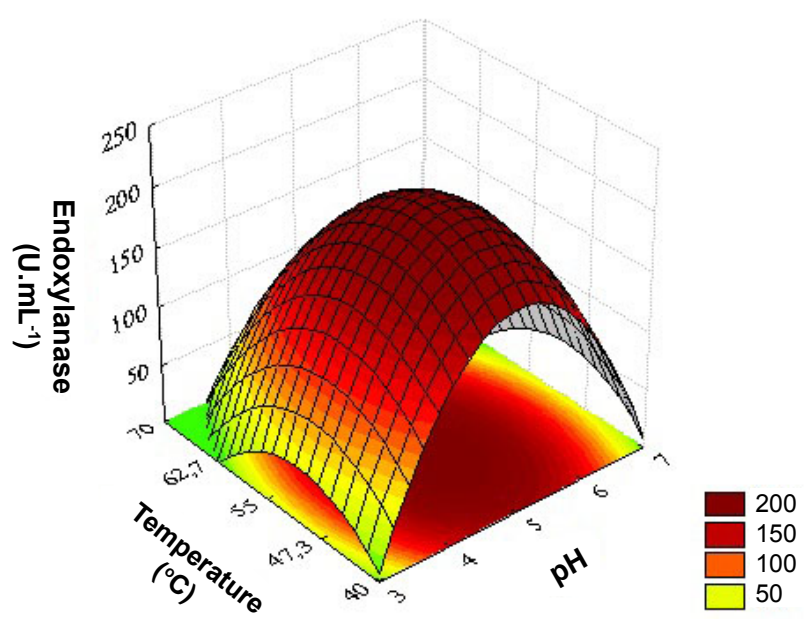

Figure 2: Response surface on partial endoxylanase characterization from $T$. atroviride $102 \mathrm{C} 1$ using $\mathrm{pH}$ and temperature as independent variables. The ful factorial central composite design $\left(2^{2}\right)$ used response surface methodology to predict the best point for endoxylanase activity. The values are shown in Table 2.

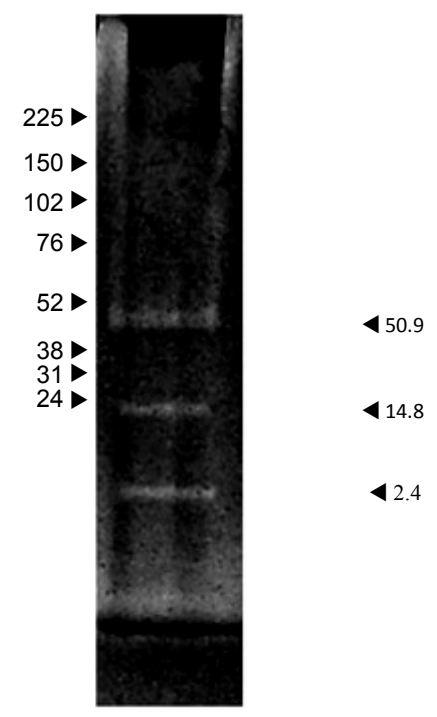

Figure 3: Zymogram analysis of endoxylanase activity in the supernatant of T. atroviride $102 \mathrm{C} 1$ cultures grown on best condition. The amounts loaded in the gel contained $150 \mathrm{mU}$ of endoxylanase activity. The gel containing the MW markers was stained for proteins using the silver staining method and values for the MW markers are shown on the left side of the Figure. On the right side are shown the apparent molecular mass of endoxylanases bands.

$(<0.1)$ indicating the significance of the model. The coefficient of determination adjusted obtained $\left(\mathrm{R}_{2}=0.89\right)$ indicates that $88.9 \%$ of the variability of the responses can be explained by the model.

The regression equations, obtained after the ANOVA, demonstrated endoxylanase activity as a function of the codified values of $\mathrm{pH}$ and temperature. The mathematical model representing the endoxylanase activity $(\mathrm{Y})$ under these conditions can be expressed by Equation (4).

$$
\mathrm{Y}=205.20-83.12 \mathrm{X}_{1}^{2}-34.06 \mathrm{X}_{2}-40.76 \mathrm{X}_{2}^{2}+0.84367
$$

The graphic of response surface (Figure 2) suggests that central area was the best condition. Based on these results, it can be stated that T. atroviride $102 \mathrm{C} 1$ produces a thermoacidophilic endoxylanase.

\section{Detection of xylanase activities through zymograms}

The zymogram analysis of the culture supernatant of $T$. atroviride $102 \mathrm{C} 1$ obtained in culture medium after growth in the optimal conditions ( 3 days fermentation, $3.5 \%$ SB and $1.1 \%$ CSL) was shown in Figure 3. Three protein bands with endoxylanase activity and estimated molecular masses of 50.9, 14.8 and $2.4 \mathrm{kDa}$ are clearly shown.

\section{Discussion}

Endoxylanases represent an enzymatic alternative strategy for access to cellulosic material, which is protected by hemicellulose and lignin in biomass. The activity of endoxylanases culminates in the generation of pentoses/hexoses, as well as other chemical compounds (acetyl and methyl groups, glucuronic acid, etc) which can be applied in various chemical industries, including bioenergy. In the present study T. atroviride $102 \mathrm{C} 1$ was tested over 5 days of fermentation for endoxylanase production. The highest production was observed on the 3rd day, where values of $266.3 \mathrm{U} \cdot \mathrm{mL}^{-1}$ of endoxylanase activity were obtained and C and N concentrations were SB 3.5\% (w/v), and CSL $1.1 \%(\mathrm{w} / \mathrm{v})$, respectively.

Endoxylanase activity is generally reported in much lower values in literature for other Trichoderma strains, especially when low-cost residues are used as substrates. For instance, Silva and Carmona [18], working with $T$. inhamatum used various lignocellulosic residues in culture medium composition which resulted in enzyme production between 0.3 and $11.37 \mathrm{U} \cdot \mathrm{mL}^{-1}$. When SB $1.0 \%(\mathrm{w} / \mathrm{v})$ was the main carbon source a production of $3.38 \mathrm{U} \cdot \mathrm{mL}^{-1}$ of xylanase was obtained. Pretreated willow, corn stover and pine, were tested as C sources for cellulases and endoxylanases production by $T$. reesei RUT C30, showing endoxylanase activity between 1.0 and $2.3 \mathrm{U}_{\mathrm{mL}}^{-1}$ [19]. In a similar study also using $T$. reesei RUT. Olsson et al. [20] observed 0.07 U.mL $\mathrm{mL}^{-1}$ of endoxylanase activity using beet pulp for production of cellulases and endoxylanases. Delabona et al. [21] described levels of 36.96 U. $\mathrm{mL}^{-1}$ of xylanase from Trichoderma harzianum P49P11 grown in steam-pretreated bagasse, $\mathrm{pH}$ 6.0, after 96 hours. Liu et al. [22] obtained higher values, between 245.0 and $300.0 \mathrm{U} \cdot \mathrm{mL}^{-1}$ for endoxylanase activity, but this was obtained after molecular vectors from Trichoderma reesei QM9414 were express in E. coli.

As far as we are concerned, there are no other citation in literature dealing with endoxylanase production when using T. atroviride, except in an earlier study by our group, where T. atroviride 676 wild type has shown ability to produce endoxylanase in amounts of $61.3 \mathrm{U} \cdot \mathrm{mL}^{-1}$, using SB 3.0\% and CSL $0.3 \%$ as $\mathrm{C}$ and $\mathrm{N}$ sources, respectively [10]. In the present research, when mutant $102 \mathrm{C} 1$ was used, a $430 \%$ increase in enzyme activity was observed, compared to the results thus reported. In addition, the high production of endoxylanase by mutant $201 \mathrm{C} 1$ occurred in the presence of sugarcane bagasse "in natura" (untreated), as observed earlier by us with the wild type 676 [10] which represents, as already stated, an economical cost-wise advantage, considering the elimination of time and efforts needed for material processing. The results here obtained for T. atroviride $102 \mathrm{C} 1$ are better than, or similar to, those observed in literature for other fungi, as Penicillium sp. [23], Aspergillus sp. [24] and Achaetomium sp. [25].

According to the results of endoxylanase produced by T. atroviride $102 \mathrm{C} 1$, the enzymatic activity can be characterized as thermoacidophilic. The $\mathrm{pH}$ and temperature profile results thus obtained, with optimum $\mathrm{pH}$ and temperature of 5.0 and $55^{\circ} \mathrm{C}$, respectively, are quite similar to those observed for other thermoacidophilic endoxylanases as those described for Fusarium proliferatum grown on xylan, where optimal 
Citation: Oliveira MMQ, Grigorevski-Lima AL, Franco-Cirigliano MN, Nascimento RP, Bon EPS, et al. (2014) Trichoderma atroviride 102C1 Mutant: A High Endoxylanase Producer for Assisting Lignocellulosic Material Degradation. J Microb Biochem Technol 6: 236-241. doi:10.4172/19485948.1000150

activity was between $\mathrm{pH} 4.5$ and 6.0 , and temperature at $55^{\circ} \mathrm{C}$ [26]. Another study concerning Aspergillus fumigatus SK1, growing on oil palm trunk, observed the optimal temperature and $\mathrm{pH}$ for endoxylanase activity as being $60^{\circ} \mathrm{C}$ and $\mathrm{pH} 4.0$, respectively [24]. Anthony et al. [27] reported higher optimal values of temperature and $\mathrm{pH}$ for endoxylanases produced by Aspergillus fumigatus AR1, using xylose or xylan as substrate: optimal temperature between 60 and $65^{\circ} \mathrm{C}$ and the optimal $\mathrm{pH}$ between 5.5 and 6.5. Lower optimal temperature (between 45 and $50^{\circ} \mathrm{C}$ ) and higher optimal $\mathrm{pH}$ (between 5 and 6) was observed for T. inhamatum when xylan was the substrate [18]. Trevizano et al. [28] obtained xylanolytic mutant strains from Orpinomyces sp with optimal temperature for enzymatic production between 60 and $70^{\circ} \mathrm{C}$ and $\mathrm{pH}$ range 5.0 to 8.0. Zhao et al. [25] observed, for an endoxylanase produced by Achaetomium sp. Xz-8, an optimal temperature between 70 and $80^{\circ} \mathrm{C}$ and $\mathrm{pH}$ between 5.0 and 6.0. So, as can be seen, results from different endoxylanase produced by different fungi grown on different substrates have different ranges of optimal temperature and $\mathrm{pH}$ being endoxylanase activity from mutant $T$. atroviride $102 \mathrm{C} 1$ grown in SB and CSL considered, in a broad range, similar to some of those already reported. The mild thermoacidophilic characteristic observed in endoxylanase activity from $T$. atroviride $102 \mathrm{C} 1$ could be very interesting when concerning biotechnological process.

The three bands observed in the zymogram for endoxylanase activity presented relatively low apparent molecular masses $(50.9,14.8$, and $2.4 \mathrm{kDa}$ ), which is in accordance with most fungal endoxylanases described in the literature $[10,22,24,25]$. Studies with T. reesei have reported two bands with apparent molecular masses of 19 and $20 \mathrm{kDa}$ [29], and 23 and $32 \mathrm{kDa}$ [30]. According to Chen et al. [31] only one endoxylanase $(37.7 \mathrm{kDa})$ was observed for T. longibrachiatum and Ang et al. [24] detected three endoxylanase $(45.7 \mathrm{kDa}, 39.8 \mathrm{kDa}$ and 18.2 $\mathrm{kDa}$ ) produced by Aspergillus fumigatus SK1. Considering the wild strain, T. atroviride 676, three different bands were found earlier by our group, with apparent values of $55.7,36.0$, and $23.0 \mathrm{kDa}$ [10], which suggests that different enzymes were expressed in the mutant strain. Zhao et al. [25] detected two bands between 43 and $55 \mathrm{kDa}$ produced by Achaetomium sp. Xz-8.

It is interesting to note that although three different enzymes were detected for endoxylanase activity produced by T. atroviride $102 \mathrm{C} 1$, it is not possible, with the data here obtained, to predict which of them is being responsible to each enzymatic activity produced. It could be all three together, as well as just one, favorable to the set of conditions of a given experiment.

Residue waste with biomass high-energy value is constantly generated by a variety of activities such as processing of agricultural products and by the paper and timber industries. However, many of these residues are difficult to be degraded and become an environmental problem. Hydrolysis of lignocellulosic biomass may play an important role enhancing the utilization of such residues. Thus, the identification of fungal strains producing high levels of endoxylanases might contribute for the use of lignocellulosic residues towards a variety of goals. In our study we used sugarcane bagasse, an abundant material, especially in Brazil, with low commercial value, as the main carbon source, and corn steep liquor, also a low-cost residue, as the main nitrogen source, to cultivate a mutant fungus strain that is a high endoxylanase producer.

While the fermentation of corn starch or sugar cane juice by S. cerevisiae is a well-established technology, the hydrolysis of lignocellulosic residues is still challenging. Therefore, the development of new organisms with lignocellulolytic capacities is crucial to make this process economically viable. We have concluded that $T$. atroviride
$102 \mathrm{C} 1$ was capable of growing and producing endoxylanases in culture medium containing SB or CSL. The best result obtained for endoxylanase production (266.3 U. $\left.\mathrm{mL}^{-1}\right)$ was better in medium containing SB 3.5\% (w/v) and CSL 1.1\% (w/v). The identified $102 \mathrm{C} 1$ mutant strain and its characterization as a high endoxylanase producer allows its use in biotechnological applications, particularly in the hydrolysis of agro industrial residues, such as sugar cane bagasse, for bioethanol production.

\section{Acknowledgement}

Authors thanks Marta de Sousa Ferreira for technical support. This work was supported by Fundação de Amparo a Pesquisa do Estado do Rio de Janeiro (FAPERJ) and Conselho Nacional de Desenvolvimento Científico e Tecnológico (MCT/CNPq)

\section{References}

1. Chi WJ, Lim JH, Park DY, Park JS, Hong SK (2013) Production and characterization of a thermostable endo-type ß-xylanase produced by a newlyisolated Streptomyces thermocarboxydus subspecies MW8 strain from Jeju Island. Process Biochemistry 48: 1736-1743

2. Deswal D, Gupta R, Nandal P, Kuhad RC (2014) Fungal pretreatment improves amenability of lignocellulosic material for its saccharification to sugars. Carbohydr Polym 99: 264-269.

3. Borges TA, Souza AT, Squina FM, Riaño-Pachón DM, Santos AC, et al. (2014) Biochemical characterization of na endoxylanase from Pseudozyma brasiliensis sp. nov. strain GHG001 isolated from the intestinal tract of Chrysomelidae larvae associated to sugarcane roots. Process Biochemistry 49: 77-83.

4. Cardona CA, Quintero JA, Paz IC (2010) Production of bioethanol from sugarcane bagasse: Status and perspectives. Bioresour Technol 101: 47544766

5. De Azeredo LA, De Lima MB, Coelho RR, Freire DM (2006) A low-cost fermentation medium for thermophilic protease production by Streptomyces sp. 594 using feather meal and corn steep liquor. Curr Microbiol 53: 335-339.

6. Nascimento RP, Alves Junior NA, Pereira Jr N, Bon EP, Coelho RR (2009) Brewer's spent grain and corn steep liquor as substrates for cellulolytic enzymes production by Streptomyces malaysiensis. Lett Appl Microbiol 48 : 529-535.

7. Pradeep GC, Choi YH, Choi YS, Seong CN, Cho SS, et al. (2013) A nove thermostable cellulase free xylanase stable in broad range of $\mathrm{pH}$ from Streptomyces sp. CS428. Process Biochemistry 48: 1188-1196.

8. Kovácz K, Megyeri L, Szakacs G, Kubicek CP, Galbe M, et al. (2008) Trichoderma atroviride mutants with enhanced production of cellulose and ?-glucosidase on pretreated willow. Enzyme and Microbial Technology 43: 4855.

9. Kovács K, Szakacs G, Zacchi G (2009) Comparative enzymatic hydrolysis of pretreated spruce by supernatants, whole fermentation broths and washed mycelia of Trichoderma reesei and Trichoderma atroviride. Bioresour Technol 100: $1350-1357$

10. Grigorevski-Lima AL, Oliveira MM, Nascimento RP, Bon EP, Coelho RR (2013) Production and Partial characterization of cellulases and xylanases from Trichoderma atroviride 676 using lignocellulosic residual biomass. Appl Biochem Biotechnol 169: 1373-1385.

11. Hopwood DA, Bibb MJ, Chater KF, Kieser T, Bruton CJ, et al. (1985) Genetic manipulation of Streptomyces, a Laboratory Manual. The John Innes Institute Norwich, United Kingdom.

12. Shirling EB, Gottlieb D (1966) Methods for characterization of Streptomyces species. International Journal of Systematic Bacteriology 16: 312-340.

13. Mandels M, Weber J (1969) The production of cellulases: Cellulases and their applications. Advances in chemistry series, vol 95 391-414. Edited by Gould RF, Washington, DC: American Chemical Society.

14. Rodrigues MI, lemma AF (2012) Experimental Design and Process Optimization. (1st edition), Casa do Pão Editora, Campinas, São Paulo, Brazil.

15. Miller L (1959) Use of a dinitrosalicylic acid reagent for determination of reducing sugar. Analytical Chemistry 31: 426-428. 
Citation: Oliveira MMQ, Grigorevski-Lima AL, Franco-Cirigliano MN, Nascimento RP, Bon EPS, et al. (2014) Trichoderma atroviride 102C1 Mutant: A High Endoxylanase Producer for Assisting Lignocellulosic Material Degradation. J Microb Biochem Technol 6: 236-241. doi:10.4172/19485948.1000150

16. Bailey MJ, Biely P, Poutanen K (1992) Interlaboratory testing of methods for assay of xylanase activity. Journal Biotechnology 23: 257-270.

17. Nascimento RP, Coelho RRR, Marques S, Alves L, Gírio FM, et al. (2002) Production and partial characterization of xylanases from Streptomyces sp. strain AMT-3 isolated from Brazilian cerrado soil using agroindustrial byproducts. Enzyme and Microbial Technology 31: 549-555

18. de Oliveira da Silva LA, Carmona EC (2008) Production and characterization of cellulase-free xylanase from Trichoderma inhamatum. Appl Biochem Biotechnol 150: 117-125.

19. Juhász T, Szengyel Z, Réczey K, Siika-Aho M, Viikari L (2005) Characterization of cellulases and hemicellulases produced by Trichoderma reesei on various carbon sources. Process Biochemistry 40: 3519-3525.

20. Olsson L, Christensen TMIE, Hansen KP, Palmqvist EA (2003) Influence of carbon source on production of cellulases, hemicellulases and pectinases by Trichoderma reesei RUT C-30. Enzyme and Microbial Technology 33: 612-619.

21. Delabona Pda S, Farinas CS, da Silva MR, Azzoni SF, Pradella JG (2012) Use of a new Trichoderma harzianum strain isolated from the Amazon rainforest with pretreated sugar cane bagasse for on-site cellulase production. Bioresour Technol 107: 517-521.

22. Liu M, Yu H (2012) Cocktail production of an endo- $\beta$-xylanase and a $\beta$-glucosidase from Trichoderma reesei QM9414 in Escherichia coli. Biochemical Engineering Journal 68: 1-6.

23. dos Reis L, Fontana RC, Delabona Pda S, da Silva Lima DJ, Camassola M et al. (2013) Increased production of cellulases and xylanases by Penicillium echinulatum S1M29 in batch and fed-batch culture. Bioresour Technol 146 597-603.

24. Ang SK, Shaza EM, Adibah Y, Suraini AA, Madihah MS (2013). Production of cellulases and xylanases by Aspergillus fumigatus SK1 using untreated oil palm trunk through solid state fermentation. Process Biochemistry 48: 1293-1302.

25. Zhao L, Meng K, Bai Y, Shi P, Huang H, et al. (2013) Two family 11 xylanases from Achaetomium sp. Xz-8 with high catalytic efficiency and application potentials in the brewing industry. J Agric Food Chem 61: 6880-6889.

26. Saha BC (2002) Production, purification and properties of xylanase from newly isolated Fusarium proliferatum. Process Biochemistry 37: 1279-1284.

27. Anthony T, Raj KC, Rajendra A, Gunasekaran P (2003) High molecular weight cellulase-free xylanase from alcali-tolerant Aspergillus fumigatus AR1. Enzyme and Microbial Technology 32: 647-654.

28. Trevizano LM, Ventorim RZ, Rezende ST, Junior FPS, Guimarães VM (2012) Thermostability improvement of Orpinomyces $\mathrm{sp}$. xylanase by directed evolution. Journal of Molecular Catalysis B: Enzymatic 81: 12-18.

29. Tenkanen M, Puls J, Poutanen K (1992) Two major xylanases of Trichoderma reesei. Enzyme and Microbial Technology 14: 566-574.

30. Gerber PJ, Heitmann JA, Joyce TW (1997) Purification and characterization of xylanase from Trichoderma. Bioresource Technology 61: 127-140.

31. Chen C, Chen JL, Lin TY (1997) Purification and characterization of xylanase from Trichoderma longibrachiatum for xylooligosaccharide production. Enzyme and Microbial Technology 21: 91-96. 